\title{
Lilija Limane
}

\section{Populāro latviešu grāmatu bilžainie vāki 19. gadsimta otrajā pusē}

Atslēgvārdi: grāmatu vāki, sižetiskās ilustrācijas, bilžainie vāki, bildes, krāsainā litogrāfija, populārā literatūra, sēriju izdevumi.

\section{Grāmatu vāku evolūcija no dekoratīva iesējuma līdz litografētajam bilžainajam vākam grāmatniecības demokratizācijas kontekstā}

Garajā attīstības ceḷā, kopš grāmatām sāka darināt vāka iesējumus, sākotnēji primāra bija grāmatas bloku aizsargājošā funkcija. Tipogrāfiski izgatavots papīra vāks ieviešas tikai 18. gadsimta beigās - agrīnākajos paraugos kā tīri dekoratīvs elements; individualizēts elements bija tikai vāka tituls. Pakāpeniski tieksme pēc dekorativitātes mazinās, arvien biežāk vāka apdari pielāgojot grāmatas saturam un piešķirot izdevumam individuālus vaibstus. Modifikācijas vāka apdarē saistītas ar lietotāju attieksmi pret attēlu. 19. gadsimtā Eiropas grāmatniecībā notiek būtiskas pārmaiņas, ko veicina apvērsums tehniskajā ražošanā un tam atbilstošs grāmatu tirgus spiediens, kuru veido lasītāju publikas pieprasījums pēc noteikta tipa grāmatām ar saturam atbilstošu ārējo veidolu.

Kaut vāku apdarei tas ir jaunums, grāmatu kultūrā zīmējuma, attēla saknes sniedzas dziḷāk vēsturē nekā tekstam, vienkāršam lietotājam tas vieglāk uztverams, tāpēc ir iecienīts arī kā grāmatu sastāvdaḷa un piedzīvo vairākas attīstības stadijas atbilstoši kultūras tipam. Rietumeiropā kopš 18. gadsimta sakarā ar grāmatu kultūras demokratizāciju plašām aprindām adresētie izdevumi tiecas pēc iespējas atvieglot uztveri, samazinot teksta apjomu, bet palielinot attēlu lomu. 19. gadsimtā plašu izplatību guva vienlapu izdevumi - ilustrētas vienlapas ar skaidrojoša teksta papildinājumiem visbiežāk folioformātā (Bilderbogen Vācijā, stampe populari Itālijā, imagerie populaire Francijā). Pētnieki saskata 19. gadsimta ilustrēto vienlapu līdzību ar logogrāfiskā rakstā veidotu tekstu, jo abi informācijas veidi sniedz lasītājam optisku signālu. Attēla un teksta vienotība arī atvieglo lasāmvielas uztveri. ${ }^{1}$ Tāpēc 19 . gadsimta pirmajā pusē Rietumeiropā ilustrētas lapas ieņem stabilu vietu populārās literatūras tirgū un strauji izplatās. ${ }^{2}$

Līdzīga funkcija populārās literatūras tirgū ir arī nelielām burtnīciņām jeb brošūrām vienas iespiedloksnes apmērā, kam parasti izvēlas oktāvformātu. Bieži vien šo izdevumu apjoms tiek paplašināts līdz 32 vai 64 lappusēm (attiecīgi divas vai četras iespiedloksnes). Līdz ar plašu aprindu piesaisti grāmatām pazeminās iespiedprodukcijas cenas. Grāmatu vākiem izmantotais plānais, bieži vien nekvalitatīvais papīrs ḷauj pazemināt pašizmaksu, grāmatas kḷūst

1 Delen, A. J. J. 1824. Histoire de la gravure dans les anciens Pays-Bas et les provinces Belges. Bruxelles: Les Editions d'Art et d'Histoire, p. 59.

2 Schenda, R. 1966. Ein französischer Bilderbogenkatalog aus dem Jahre 1860. In: Schweizerisches Archiv für Volkskunde, Bd. 62, S. 52. 
lētākas, 19. gadsimta 40. gados Vācijā burtnīcu tipa grāmatas plānos vākos gūst masveida izplatību, tiek pārdotas dzelzceḷa stacijās un citās tirdzniecības vietās ārpus grāmatu veikaliem. Plānās brošētās grāmatinas ar ilustrētiem vākiem Rietumeiropas bibliotēkās uzkrājušās simtos tūkstošos nosaukumu, piemēram, franču kolportāžai paredzētais katalogs 1858. gadā ietver 8000 šādas literatūras nosaukumu. ${ }^{3}$ Masveidā atražotie tipveida grāmatinu teksti un ilustrētie vāki iegūst starptautisku raksturu, valodas barjeras tiek pārvarētas ar tulkojumu starpniecību. Tehniskās inovācijas un masu lasīšana ir savstarpēji saistītas lietas un to cēloṇsakarība - abpusēja, lai gan daži zinātnieki, piemēram, Martins Laionss (Martin Lyons; 1946) uzskata, ka grāmatu ražošanas industrializāciju veicina tirgus spiediens. ${ }^{4}$

Līdz ar saturu un vizualitāti pārmaiņas piedzīvo publikāciju veidi. Kā Francijā, tā Vācijā un citviet Rietumeiropā kopš 19. gadsimta 20. gadu beigām populārās tautas grāmatiņas izdevēji apvieno sērijās, kas līdz ar apdares īpatnībām ḷauj pircējiem tās atpazìt. Sēriju izdevumi kḷuva l̦oti populāri, reizēm sasniedza vairākus simtus laidienu un nenozuda no veikalu un mājas bibliotēku plauktiem līdz 20. gadsimta sākumam. Ar sēriju un periodiskajā presē turpinājumos publicēto daiḷliteratūru izdevēji veido jaunu mārketinga stratēǵiju, piesaista bestselleriem reklāmas, sludinājumus, plakātus. ${ }^{5}$ Pats izdevuma veids funkcionē kā komerciāla reklāma, pastiprina citus reklamēšanas paṇēmienus, jo izdevēji rēḳinās ar lasītājiem, kas sagaida standartizētu iespiedproduktu. Rietumeiropas zemēs atbilstoši teksti tiek pat

3 Chabouillet, J. M. A. 1858. Catalogue général et raisonné des camées et pierres gravées de la Bibliotheque Impériale... Paris: Claye.

4 Lyons, M. 2010. History of Reading and Writing in the Western World. New York: Palgrave Macmillan, p. 138.

5 Law, G., Patten, R. L. 2009. The serial revolution. In: The Cambrige history of the Book in Britain. Vol. 6, 1830-1914. Cambridge: Cambridge University Press, p. 144-171. autoriem pasūtīti. Tā kā latviešu literārais tirgus nav pietiekams, lai pats sevi apgādātu ar literatūru, tiek izmantoti starptautiskie paraugi, ko literāti pēc izdevēja pasūtījuma tulko vai adaptē, tādējādi rakstniekiem kḷūstot par tādiem tekstu producētājiem, kas orientēti uz peḷnu. Šo grāmatu vāks sasaucas ar saturu tik, cik nepieciešams iespaidot pircēja izvēli, tas identificē grāmatas piederību noteiktai literatūras grupai, kas atbilst lasītāja gaidām un garantē atbilstību standartam. Izdevējiem bija svarīgi nevis tas, no kurienes ņemts plāno izdevumu vāka attēls un kas to radījis, bet gan tas, kāds tas ir un vai spēj ietekmēt pircēju.

\section{Bilžainais vāks kā ilustrētā vāka tips}

Latvijā triviālliteratūras izdevumiem raksturīgie ilustrētie vāki guva plašu izplatību 19. gadsimta 70. gados un piedzīvoja ziedu laikus līdz 20. gadsimta sākumam. Šajā rakstā ar bilžaino vāku tiek saprasts populārajām neliela apjoma grāmatām raksturīgais mākslinieciskā ziņā problemātiskais ilustrētā vāka attēla tips, kurš iespiests uz plāna papīra un kura priekšējo vāku visā tā apjomā aizṇem grāmatas satura epizodei atbilstoša krāsaina sižetiska ilustrācija - bilde. Terminu "bilžainais vāks" literatūrā ieviesa bibliogrāfs Jānis Misiņš ${ }^{6}$, kas, šķiet, precīzi raksturo vāku, tāpēc šajā rakstā lietderīgi saglabāt šo terminologijiju. Jo īpaši tādēḷ, ka jaunāko paaudžu grāmatniecības vēsturnieki nepietiekamā mērā analizējuši bilžainos vākus: grāmatniecības vēsturnieks Aleksejs Apīnis tos piemin tikai garāmejot, nodēvējot par "sentimentālām bildītēm" , grāmatu mākslas vēsturnieks Valdis Villerušs tās dēvē par "hromolitografētām kompozīcijām" un raksturo kā amatnieciskas, reizēm pat nemākulīgi

6 Misiņš, J. 1925. Latviešu rakstniecības rādītājs. 2. sēj. Rīga: Kultūras fonds, 18.-46. lpp.

7 Apīnis, A. 1977. Latviešu grāmatniecība: no pirmsākumiem lìdz 19. gs. beigām. Rīga: Liesma, 323. lpp. 
izpildītas. ${ }^{8}$ Analogu terminu nav izdevies atrast arī cittautu grāmatu mākslas vēsturē, kur nepietiekami akcentētas mākslinieciski mazvērtīgas parādības, lietoti tādi termini kā cheap straw pulp cover, bibliotheca blau, Bilderbücher. ${ }^{9}$

Latvijā bilžaino vāku producēšana iet kopsolī ar krāsainās litogrāfijas ieviešanu grāmatrūpniecībā, kas līdztekus mašinizētajai ražošanai rada apvērsumu vāka noformējumā un ko Eiropas grāmatu iespiešanā sāk lietot ap 1860. gadu. Latviešu grāmatās, kulminējot 80. gadu vidū, bilžaino vāku producēšanas intensīvākais posms ir no 70. gadiem līdz 20. gadsimta sākumam, bet tā tika lietota arī vēlāk. Litogrāfiju - gludspiedes pan̄ēmienu, kas balstīts uz krāsas pievilkšanu no taukiem un atgrūšanu no ūdens, - eksperimentu rezultātā atklāja Āloiss Zēnefelders (Aloys Senefelder; 1771-1834) 18. gadsimta beigās. ${ }^{10}$ Krāsas un spilgtums grāmatu apdarē ieviešas, pateicoties mūsdienu ofsetdrukas priekštecei hromolitogrāfijai jeb krāsainajai litogrāfijai. ${ }^{11}$ Reproducējamos tekstus un ilustrācijas zīmē uz speciāla litogrāfijas akmens ar taukainu tušu, krītinu vai otu, no zīmējuma iegūst novilkumu. Lai iegūtu daudzkrāsainu attēlu, izmanto vairākas litogrāfijas plates, katrai krāsai savu. Atšḳirīibā no gravīrām, litogrāfija māksliniekam ḷauj veidot darbus tieši akmenī, tas paātrina ilustrāciju tapšanas procesu. Hromolitogrāfijas paņēmiens

8 Villerušs, V. 1986. 19. gadsimta latviešu grāmatu tipogrāfisko papīra vāku informatīvā funkcija. No: Grāmatas un grāmatnieki: Misina bibliotēkas 100. gadadienai, 1885-1985. 2. izd. Rīga: Zinātne, 155. lpp.

9 Lexikon der Buchkunst und der Bibliophilie. 2006. Hamburg: K. K. Walther; Harthann, J. 1997. The History of the illustrated Book: the Western tradition. London: Thames and Hudson; Lexikon des gesamten Buchwesens. Bd. 1. 1987. Stuttgart: A. Hiersemann, S. 141; Schlagintweit, H. 1983. Reproduktionslithographie: Studien zur Funktion technischer, sozialer und komerzieller Vorgaben in der Bilderproduktion des 19. Jahrhunderts. Diss. München.

10 Lexikon der Buchkunst und der Bibliophilie, S. 266. 11 Turpat, S. 268. lauj reproducēt gleznieciskus daudzkrāsu attēlus, kuru virsma ir gluda un mazliet atgādina ellıas gleznu, piešķirot attēlam telpiskumu. Bildes "dzīvums" ir viens no iemesliem, kādēḷ tās skatītājos, īpaši bērnos, izraisīja stipru emocionālo iespaidu. N̦emot vērā jaunās tehnoloǵijas zemās izmaksas, radās iespēja piedāvāt pircējam vizuāli spilgtu produktu par zemu cenu. Neskatoties uz krāsu košumu un vizuālo spilgtumu, būtu nevietā runāt par grāmatu apdares mākslinieciskās kvalitātes paaugstināšanos, it īpaši tāpēc, ka hromolitogrāfiju plaši lietoja tieši grāmatniecības zemākajā nišā, veidojot vienkāršotajam saturam atbilstošus attēlus.

Hromolitografēto vāka attēlu pagatavošanai plaši lietoja plānu, zemas kvalitātes papīru, kas noteica grāmatu īso mūžu - vāka aizsargfunkcija bija nesalīdzināmi zemāka nekā ādas vai papes iesējumiem. Tādēḷ tipogrāfiskos papīra vākus visbiežāk lietoja lētu, īslaicīgas nozīmes sacerējumu iesiešanai. Hromolitografēto vāka bilžu pavadtendence ir grāmatas formāta samazinājums, Latvijā šiem izdevumiem tipisks bija astotdaḷformāts. Arī grāmatu apjoms nav liels, vidēji ap 50-60 lappušu.

Melnbaltā litogrāfijas tehnika papildināja tipogrāfijas iekārtu klāstu daudzās Latvijas spiestuvēs jau 19. gadsimta sākumā, bet pēdējā trešdaḷā to skaits strauji auga. 70. gadu sākumā grāmatās krāsainu bilžu klātbūtne ir vēl jauna, bet publikā pamanīta parādība. C. H. Bertrams raksta: "Līdz ar grāmatu ir arīdzan bilžu drukāšana šinīs dienās savu jauku pienemšanos visādā skaistā dailībā parādījuse."12 70. gados Jelgavā bija trīs litogrāfijas, bet 90. gados Rīgā jau 20 tipolitogrāfijas un trīs litogrāfijas (bet tikai viena hromolitogrāfija), provinces pilsētas tehnoloğiskā ziṇā atpalika, un Vidzemē tipolitogrāfija bija tikai Valkā. ${ }^{13}$ Strauji augošais litogrāfiju skaits tomēr ne vienmēr spēja

12 Bertram, C. H. 1872. Kādas ziṇas par grāmatu drukāšanu. Latviešu Avīzes, Nr. 29, 19. (30.) jūl., 229. 1pp.

13 Iekšzemes zinas. 1897. Dienas Lapa, Nr. 100, 3. maijs, 2. lpp. 
nodrošināt atbilstošas kvalitātes krāsainus attēlus. Vāka bildes pagatavoja tikai dažās tipogrāfijās, kas bija spējīgas nodrošināt atbilstošu kvalitāti, - visproduktīvākā bija Stefenhāgenu firma Jelgavā $\overline{1}^{14}$, tai sekoja Heinrihs Alunāns Jelgavā un M. Jākobsons Rīgā. Vēlīnāk bilžainus vākus atsevišķos gadījumos darināja arī citās darbnīcās ārpus lielajiem centriem, piemēram, Liepājā. Bilžu autori grāmatās nav norādīti, un nav arī iegūta informācija par tiem, taču noprotams, ka tās lielākoties ir ārvalstu, domājams, vācu meistaru, darbu kopijas. Vietējo meistaru darbi vāku apdarē ir reti konstatēti (piemēram, daži Mārtiņa Buša (1855-1930) kokgrebumi atseviškiiem Johana Frīdriha Šablovska (1840-1918) izdevumiem) un amatieriski. ${ }^{15}$ Arī Rietumeiropas zemēs populārās literatūras sēriju neatnemama sastāvdaḷa bija vāks ar tautas bildītēm, Latvijā tipiskie izdevumu veidi no turienes importēti. Domājams, ka tika iepirkti lietoti litogrāfijas akmeñi. Iespējams arī, ka vietējie amatnieki apstrādāja importēto mākslinieku zīmējumus un sagatavoja iespiežamās formas, no gatava zīmējuma pārkopēja attēlu litogrāfijas akmenī, sagatavoja krāsas, apkalpoja spiedi utt. Attēla idejas un kompozīciju noteica aizgūts mākslinieciskais risinājums, bet tehniskais izpildījums bija vietējo meistaru rokās. No viṇu prasmēm bija atkarīga kontūru kontrastainība un krāsu tīrība. Ilustrētie vāki tiek lietoti atbilstoši izdevēju rocībai un vēlmēm, bet sākotnēji tie raksturīgi dažu vadošo triviālliteratūras izdevēju grāmatām, toties mācību un populārzinātniskās literatūras apdarē litogrāfijas tehniskās iespējas tiek izmantotas izzinošu attēlu darināšanai.

\section{Bilžaino vāku lietojums populārās literatūras sēriju apdarē}

Bilžainais vāks ir viena no literatūras sērijveida izdevuma pazīmēm. Atsevišķiem, sērijās neietilpstošiem izdevumiem bilžainos vākus izmanto tikai retos gadījumos. Sēriju princips reprezentē noteikta veida literatūras stilistiskās klišejas, reproducē sižetiskas shēmas, standartam atbilstošus personāžus un situācijas, bet arī noteiktu ārējo formu: izdevuma formātu, pircēju piesaistošu specifisku vāka noformējumu. ${ }^{16}$ Vāki atbilst tautas literatūras saturam un pārstāv no viena darba otrā pārnemtus radniecīgus motīvus. Tādējādi vāks signalizē lasītājam par piederību noteiktam žanriski tematiskajam kanonam. Šis kanons reprezentē plašās l,aužu aprindās iecienīto vieglo lasāmvielu jeb, mūsdienu terminologijiā, populāro literatūru. Vāks kḷūst par masu literatūras industrijas būtisku un neatņemamu sastāvdaḷu un kalpo plašu iedzīvotāju aprindu izklaides vēlmei, kas atbilst tirgus prasībām. Vieglās lasāmvielas sludinājumos izdevēji piedāvā šīs grāmatas, kā īpašu vērtību uzsverot tās "mākslinieciski izstrādātu vāka gleznu".

Košās litografētās vāka ilustrācijas sevišksi bija iecienījuši vieglās lasāmvielas izdevēji J. Šablovskis Jelgavā, M. Jākobsons Rīgā, kā arī Heinrihs Alunāns (1835-1904) Jelgavā. Šablovskis sērijā "Tautas bibliotēka" 30 gadu laikā (1875-1904) laida klajā 80 numurus, saglabājot nemainīgu vāka apdares struktūru: ilustrācija aizṇēma visu vāku, ietverta dažādu krāsu papīra rāmī. Augšmalā virs bildes tika uzdrukāts sērijas nosaukums un laidiena kārtas numurs, uz gaiša četrstūra grāmatas nosaukums, bet apakšmalā līdzīgi: uz gaišā krāsā nodalītas joslas grāmatas teksta citāts, kas papildina attēloto situāciju. (1) Šāds vāka izkārtojums ir pārskatāms, tekstu nodalīšanas

16 Schenda, R. 1977. Volk ohne Buch: Studien zur Sozialgeschichte der populären Lesestoffe, 1770-1910. München: Deutschen Taschenbuch-Verlag, S. 277-278. 
paņēmiens ḷauj tos ātri saskatīt un uztvert, netraucējot bildes uztverei. Šablovskim nebija savas tipogrāfijas, tāpēc grāmatu teksti, tāpat kā vāki, darināti pēc pasūtījuma vairākās Jelgavas spiestuvēs - visbiežāk pie J. F. Stefenhāgena vai Heinriha Alunāna, dažas grāmatas iespieda arī A. Reinbergs.

M. Jēkabsons darbojās Rīgā un sērijā "Īstā tautas bibliotēka” izdeva 31 stāstu grāmatu. Viņa izdevumu vāku apdare nav tik vienveidīga kā "Tautas bibliotēkas" laidieniem. Neiztrūkstošs tekstuālais elements ir grāmatas nosaukums, turpretim sērijas nosaukums un laidiena numurs uz vāka te parādās, te tā trūkst. Nav arī teksta citātu, tātad nav paskaidrojumu par bildē attēloto situāciju. Arī nospieduma kvalitāte nav pietiekami kontrastaina un visumā atpaliek no jelgavnieku poligrāfiskās kultūras. Reizēm attēls ievietots geometriskā rotājuma apmalē.

Bibliotēku krājumos konstatēti arī daži eksemplāri no H. Alunāna piedzīvojumu un kriminālliteratūras sērijas "Bibliotēka" astoņiem laidieniem. Alunāns izvēlējies kvadrātveida formātu, nedaudz mazāku nekā Šablovskim, bet poligrāfiskais izpildījums kvalitatīvs. Informācija uz vāka: grāmatas nosaukums un teksta citāts, toties trūkst sērijas nosaukuma (ir tikai numurs).

Citas sērijas atkārto minēto sērijas vāka apdari, bet ir skaitliski maznozīmīgas. Piemēram, Andreja Auziņa "Vispārējā tautas bibliotēka" apstājas pie vienīgā izdevuma - Čārlza Dikensa "Sīkstuḷa", bet liepājnieks Klāvs Ukstinšs (1832-1904) sērijā "Jaunā tautas bibliotēka" sarūpē divas grāmatas. 3 Arī Pūcīšu G̦ederta (1847-1919) sērijai nav ilgs mūžs.

Visās sērijās ietilpstošajās grāmatās trūkst teksta ilustrāciju vai, ja atsevišḳos gadījumos tās ir, tad melnbaltas. Atsevišķ kus, pie sērijām nepiederošus stāstu izdevumus bilžainos vākos tērpa reti. Kā viens no šādiem piemēriem minams A. Burzeta fantastiskais stāsts "Laupītāju vadons Bernards" (uz vāka "Laupītāju virsnieks"; 1885), kas Pūcǐšu G̦ederta apgādībā iespiests M. Jākobsona drukātavā. (4) Pa kādai krāsainai bildei mēdza ievietot burtnīcu romānu tekstā vai prettitulā, vākus atstājot bez ilustrācijām.

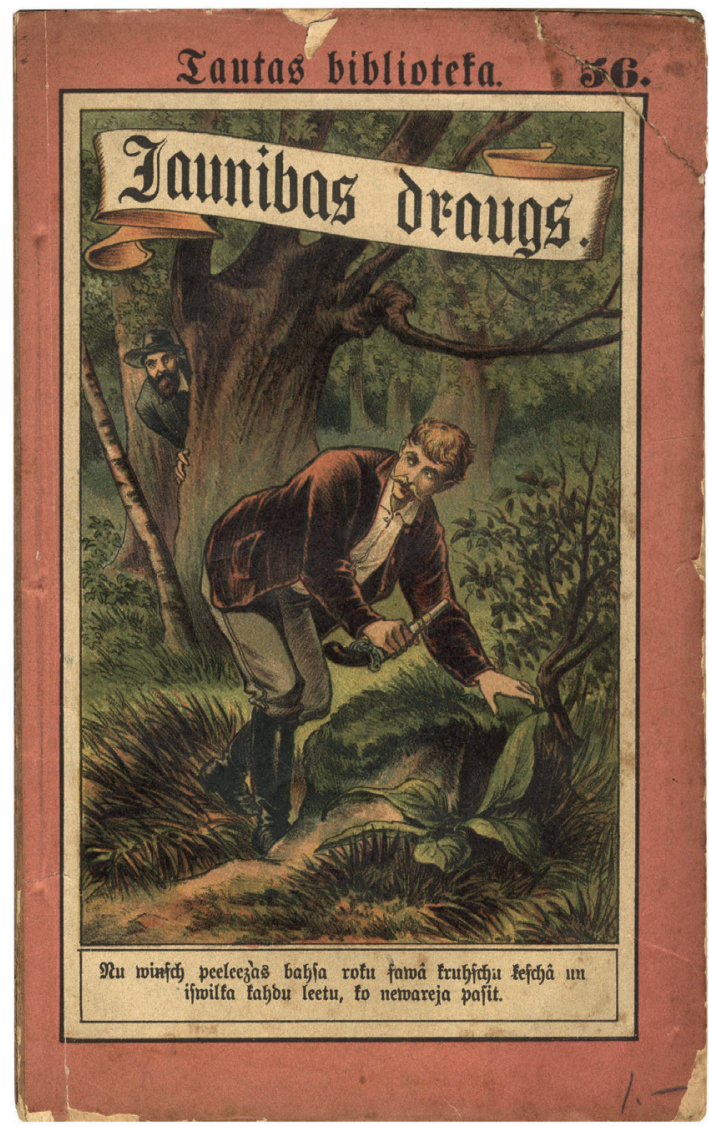

F. Frīdriha grāmatas "Jaunības draugs" (Jelgava: J. Šablovskis, 1887) vāks 
48

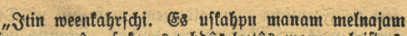
ebrfelim mugurâ, uf to eș taboâs leetâs waru palaifteess. nemaru finat. - ui reofefdanos beebri! - Majora tungs!"

„Ro pareblat, wixfneeta funģ

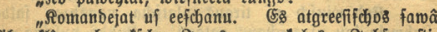

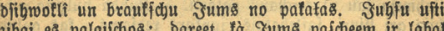

283aj fini fo, Richard," apfreizinaja roizu bruhte; es méginaju famas azis laffíçanâ."

"Эัa. Bet fafi man, fas tif ftaifti un rittigi raffta,

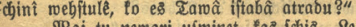

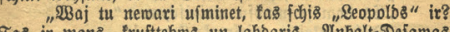

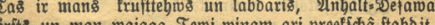
"Rad un fur?

"Iithtâ ieb parift Drefbenê.."

"iad man buhs breermigas bailes! "

tomebr foti laipnis un labprabtias." iituretees, là tahba leelfunbje!"

תRam majabfigs un witzids to ari negrib. (f) mizu ufrunaichu it meenfabridi un ftabsifकu Temi ta preetfjâ."

"Tax peentebru, fa? "Oruitables rofi". un panabzu to. - Stabos wina liftens bubs, to es zibai es palaildos, baceet, th

"283aj maxi lofit?"

"Rad un fur?

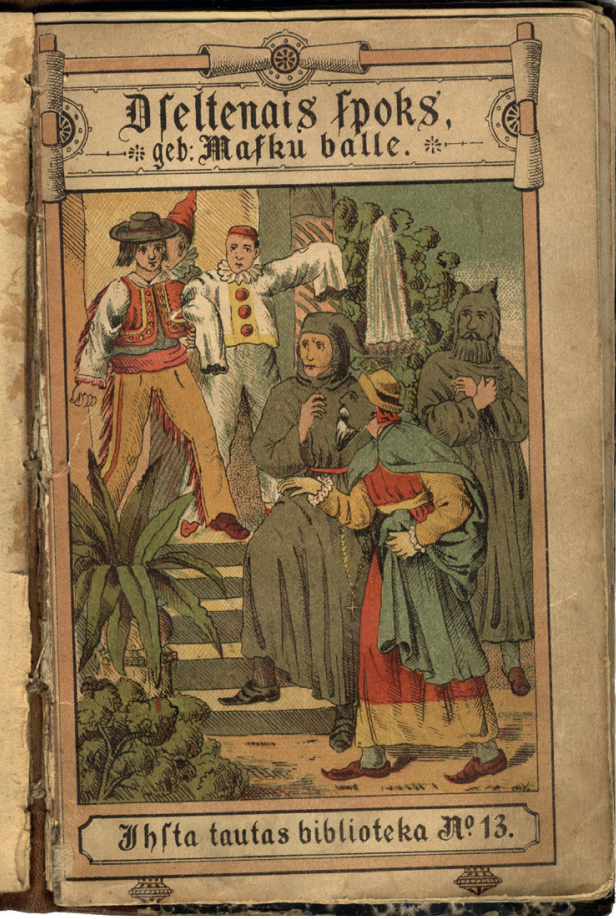

(2) Grāmatas “Dzeltenais spoks jeb masku balle" (Rīga: M. Jākobsons, 1886) vāks. Tulkojis Voldemārs Millers

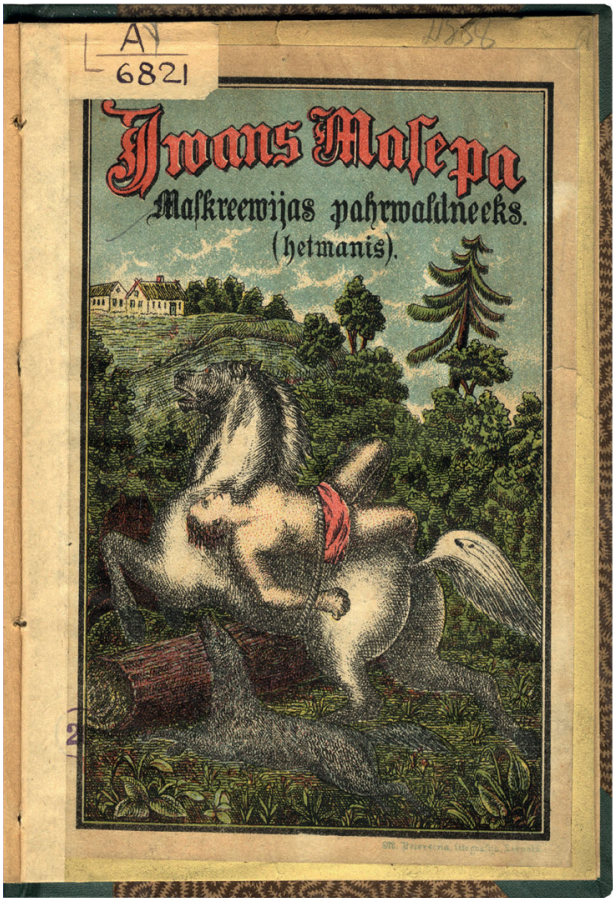

3 Grāmatas "Ivans Mazepa, Mazkrievijas pārvaldnieks (hetmanis)"

(Liepāja: K. Ukstiņš, 1883) vāks

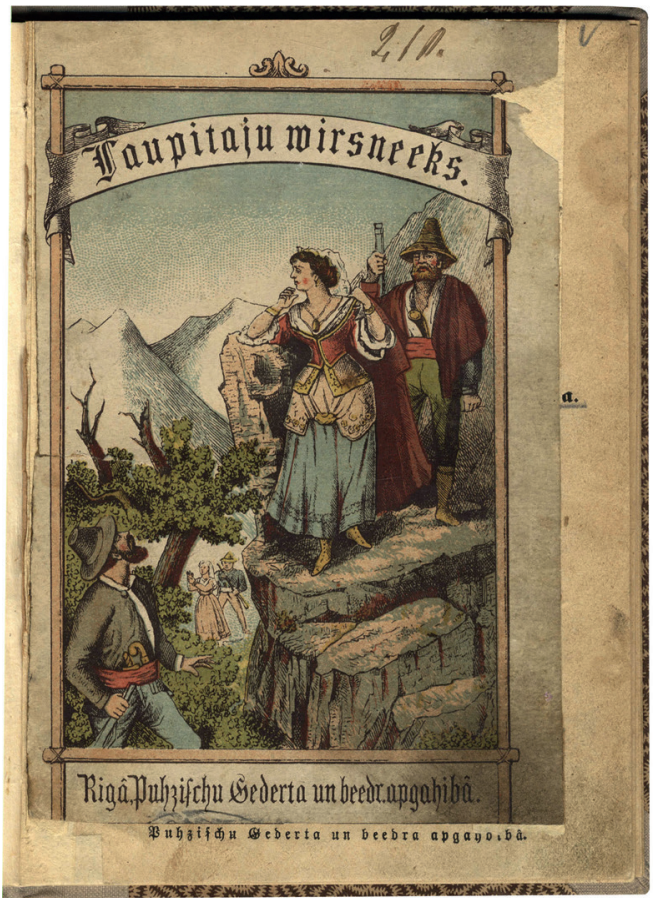

A. Burzeta grāmatas "Laupītāju virsnieks" (Rīga: Pūcišu G̦ederts, 1885) vāks 

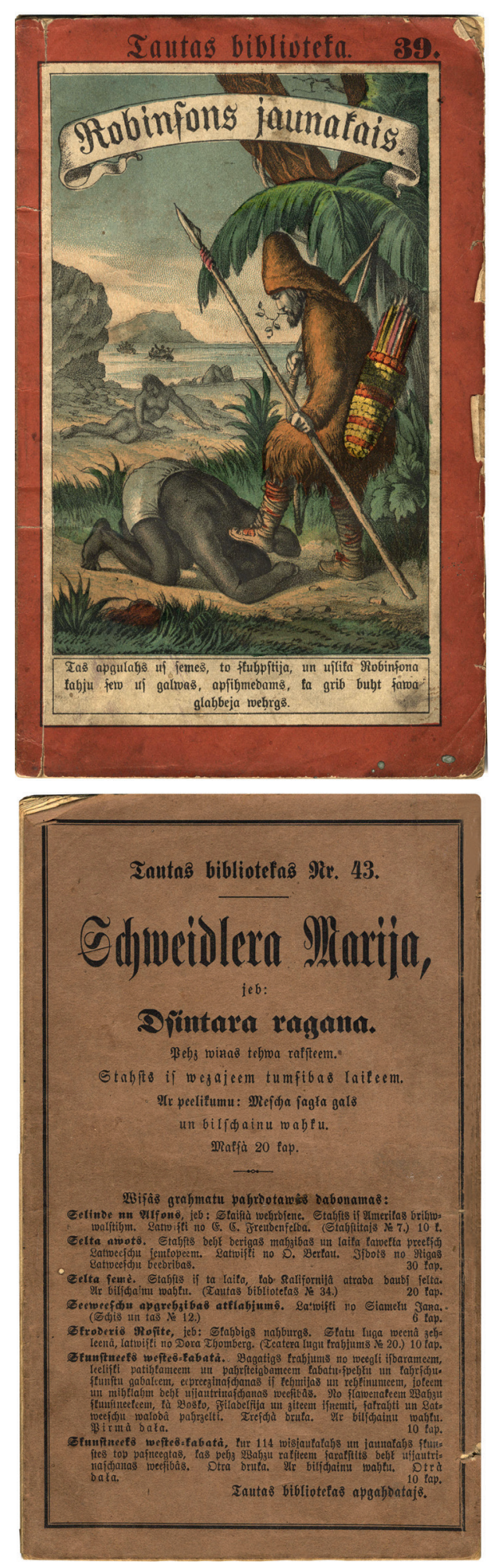

5 J. H. Kampes grāmatas "Robinsons jaunākais" (Jelgava: J. Šablovskis, 1885) priekšējais un aizmugurējais vāks
Tendence veidot bilžainus vākus arī burtnīcu romāniem pieaug laika ritējumā, piemēram, 20. gadsimta sākuma detektīviem tie ir pat tipiski, un to tradīcija sakņojas 19. gadsimta sēriju izdevumu apdarē.

Pie bilžainā vākā tērpto grāmatu apdares pieder arī ceturtā vāka noformējums (vāku iekšpuses parasti netika apdrukātas, plānais vāku papīrs arī nepieḷautu tā divpusēju ilustrēšanu). Uz tā parasti izvietoja izdevēja reklāmu - grāmatu sarakstus vai ieteicošas anotācijas par kādu atsevišḳu jaunizdoto grāmatu. (5)

\section{Vāka informatīvi vizuālais veidojums}

Kā norādīts iepriekš, vāka bildei pievienotie tekstuālie elementi variējas no sērijas uz sēriju, bet galvenie ir šādi: visiem izdevumiem obligāts elements - grāmatas nosaukums, grāmatu grupas atpazīstamību veicinošs sērijas nosaukums un kārtas numurs, ilustrācijas izpratni padziḷinošs ar bildi saskaņots teksta citāts. Citāti palīdz atklāt uz vāka redzamā personāža îpašības, bagātinot vāka informāciju.

Vāka centrālā un vizuāli pievelkošākā daḷa hromolitogrāfijas tehnikā izpildītā sižetiskā ilustrācija - grāmatas apdarē ievieš krāsainību un raibumu un krasi kontrastē ar citās tehnikās darinātajiem vākiem, tās galvenā funkcija - būt pamanāmai, ātri iespaidot un ieintriǵèt. Ilustrāciju mākslinieciskais izpildījums pārsvarā ir amatierisks, attēlotās ainas klišejiskas. Vāka kompozīcijās attēlotais personāžs (literārie varoņi) pakārtots sižeta līnijai un ir centrālās idejas nesējs. Attēloti nevis statiski objekti vai literāro varoṇu portreti, bet darbība, tātad bilde ir sižetiska kompozīcija, kas vizualizē kādu teksta vietu. Ilustrācijās attēlotā epizode netiek izraudzīta nejauši, bet tver kādu kulminācijas punktu stāstā, bīstamas vai izšķirošas situācijas. Tāpēc bilde izraisa asas emocijas un vedina iepazīties ar literāro materiālu. Iespaidu pastiprina krāsainās litogrāfijas tehnikas panāktais telpiskuma efekts. Bilžu lapas parasti apdzīvo vairāki varoṇi, tā ir kāda tikšanās, darbība, cīṇa, izškirošs notikums, l̦oti bieži darbība 
norisinās eksotiskā vai krāšņā dabā, netrūkst arī pret pretinieku pavērstas pistoles. Varoṇi pirāti, laupītāji, spoki, augstmaņi, kā arī sievietes visbiežāk dramatiskā vai emocionāli sakāpinātā, vai trağiskā brīdī. Redzamie cilvēki, dzīvnieki un vide ne tikai rada emocionālo noskaņu, bet arī ieved potenciālo lasītāju neierastā vidē, sevišķi tad, ja stāstu darbība norisinās eksotiskās zemēs vai neparastās vietās. Tādējādi bilžaino vāku raibums, dinamika un no ierastās vides atrautā tēlainība spēja kāpināt interesi par grāmatas saturu, kas solīja neparastus piedzīvojumus.

\section{Bilžu motīvi un stilistika}

Bilžu motīvus var iedalīt divās lielās pamatgrupās: ikdienas tēlojums, tostarp mīlestības sarežğījumi, un piedzīvojumu literatūra - notikumi uz jūras, eksotiskās zemēs, uz vientuḷām salām, neparastos apstākḷıs. Kara attēlojums ir piedzīvojumu literatūras agrīnākais paveids, kura popularitātes cēlonis meklējams cīṇas asumā. Arī laupītāju romāni un kriminālas intrigas pieder pie šĩs literatūras grupas.

Sadzīves tēlojumos situācija bieži vien ir dramatisks, emocionāli piesātināts vai izšḳirošs brīdis cilvēka liktenī, varonis atrodas pat dzīvības apdraudējuma priekšā. Piemēram, Cielavìte sēž raudoša mežā uz celma, vaimanādama čukst: "Dievs, kāpēc tu man to esi darījis."17 Jānopērk grāmata, lai uzzinātu, kas bija tas cilvēks vai apstākḷi, kas nabaga meiteni noveduši tik bēdīgā bezizejas situācijā. Stāstā "Ulāna sieva" atainots sievas un bērna škiršanās brīdis no vīra - varbūt uz mūžu, jo vīrs aiziet karā. ${ }^{18}$ Kādā citā attēlā traǵēedija jau notikusi vīrs ielicis mirušās sievas galvu savā klēpī un izmisumā piekēries stabam. Kādreiz ar cilvēku notiek kas krass un ass - viņš krīt, gāžas, ir ievainots, to apdraud zvēru uzbrukums vai notiek kāda cita riskanta darbība. Kādreiz konflikts ir noslēpumains, citreiz nepārprotams, piemēram,

17 Frīss, N. 1898. Cielavìte. Jelgava: J. Šablovskis. 18 Frīss, N. 1898. Ulāna sieva. Jelgava: J. Šablovskis.

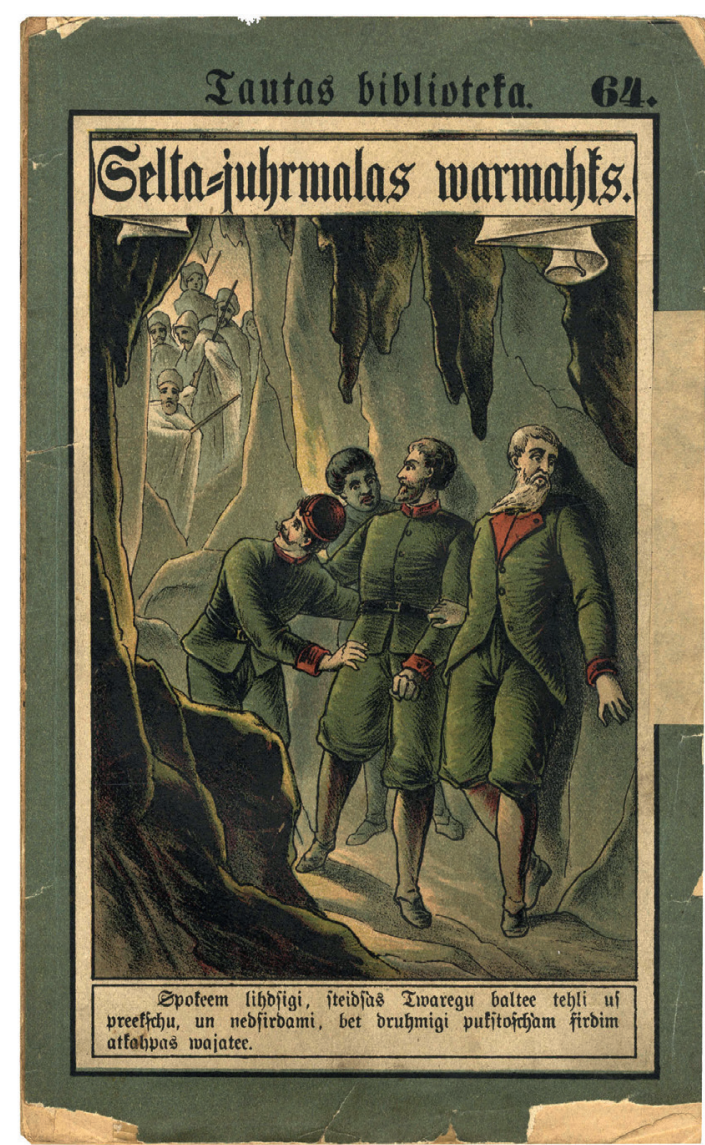

6. Hokera grāmatas "Zelta jūrmalas varmāks" (Jelgava: J. Šablovskis, 1898) vāks 
strīds aci pret aci vai indēšanas aina. Tipiskas bilžu ainas ir konflikts - kaušanās uz kuğa, cīṇa kara laukā, vīru saḳeršanās divcīṇā, notiek pakaḷdzišanās, bieži kādam ir ierocis rokā un kāds ir apdraudēts. Nereti bildēs ar spokiem vai skeletiem atainoti šausmu momenti, lai izraisītu mistiskas vai reālas bailes.

Pie bilžu grāmatu letēm valdošo gaisotni raksturo pedagoga Roberta Bīlmaņa nikni izteikts secinājums, ka pie katra avī̌̌u pārdevēja varot ieraudzīt veselu izstādi bilžainas lubu literatūras, uz kuru ielas publika krītot kā mušas uz medu, taču to nesmādē arī pieaugušie: "Nāk māmiņa ar iepirkumiem - apstājas, nāk strādnieks, pārdevēja, skolnieks, ǵimnāziste, ierēdnis ar zīmi pierē, students, nāk glīti gērbušās dāmas - visi apstājas un garā virknē kā dzelzceḷa piestātnē pie kases, visi gaida izdevības pieiet tuvāk apskatìt, kā nejēdzīgi uzzīmētie gaisa kugotāji viens otram šḳēpu cauri dur, kā šrapneḷi sprāgst utt."19

Bildē nereti ieprogrammēts adresāts pēc dzimuma vai vecuma. Ja redzami supermeni ar automātiem - tātad gaidāms piedzìvojums un lasītāji būs pusaudži; ja maskulīni varoṇi - tas var būt sieviešu romāns. Bezvainīga, jauna un skaista meitene liecina par romantiskas ievirzes sižetu sievietēm.

Lubu literatūras sekmes grāmatu tirgū nosaka veiksmīga nosaukuma izvēle, jo nosaukums ir grāmatas satura izteicējs un lasītāju pievilinātājs vienlaikus, it îpaši, ja uz vāka trūkst atsauču uz iecienìtu autoru vai kādu citu literāra darba atpazīstamības faktoru. Ar nosaukumu sākas autora saruna ar lasītāju, tāpēc tam jāprovocē uz dialogu, nosaukumā iekodēts teksta interpretēšanas virziens, tātad nosaukumam vajadzētu izteikt teksta būtību. Populārās literatūras jomā nosaukuma uzdevums ir piesaistìt lasītāja uzmanību un palīdzēt vinam izvēlēties grāmatu. Ja lasītājs sāk grāmatu lasīt, nosaukums savu uzdevumu ir paveicis. Krievu

19 Bīlmanis, R. 1914. Latviešu lubu literatūras valstībā. No: Mūsu kalendārs 1915. gadam. Rīga: Izglìtība, 66. lpp.

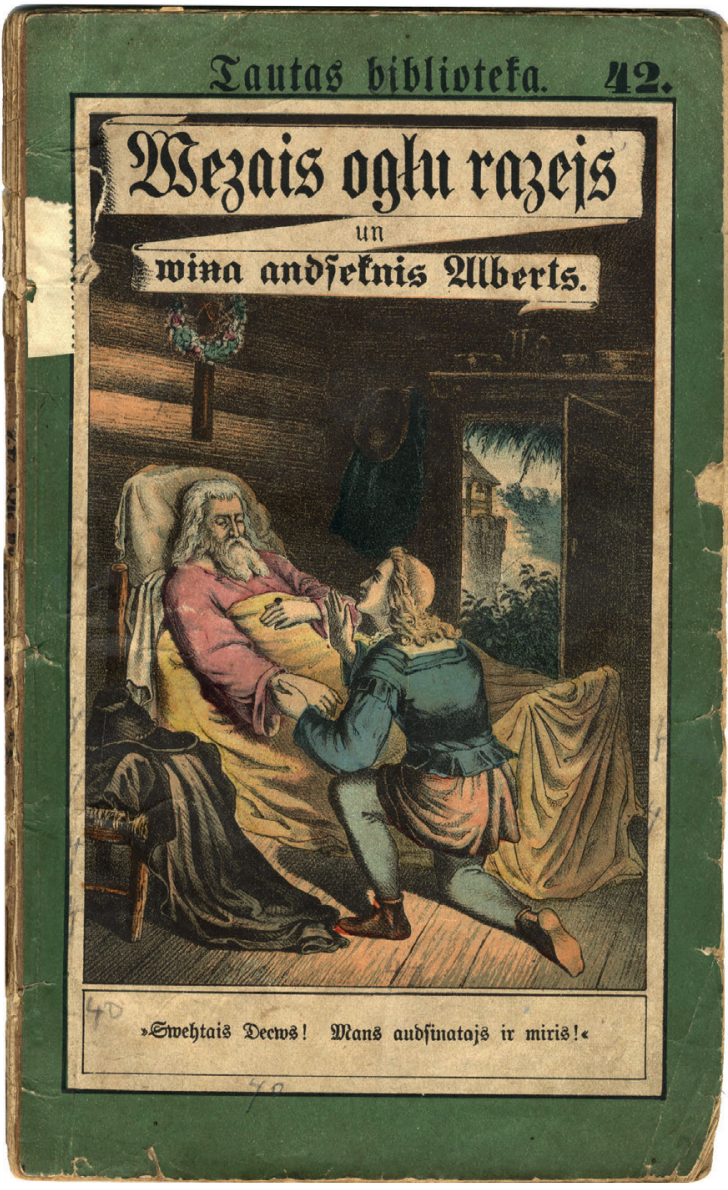

K. Šmīda grāmatas "Vecais oglu racējs un viṇa audzēknis Alberts" (Jelgava: J. Šablovskis, 1886) vāks 
izdevējs Aleksandrs Smirdins (Александр Смирдин; 1795-1857) uzskatīja, ka nosaukums nosaka stāsta vai romāna likteni. ${ }^{20}$ Populāros romānus un stāstus pēc nosaukumiem viņš iedalīja trīs galvenajos tipos: l̦oti briesmīgs, l,oti līdzcietīgs vai smieklīgs. Tas nekas, ka nosaukumi nereti nemaz neatbilda saturam vai pat bija tāli pēc to būtības. Parasti nosaukumā ietvertā ideja atbilst žanra kanonam. Kriminālromānu nosaukumi stilistiski un saturiski būtiski atškiras no romantisko mīlestības vai sadzīves romānu nosaukumiem. Dāmu beletristikā atslēgvārdi ir, piemēram, mīlestība, sirds, lakstīgala, skūpsts u. tml. Laupītāju romānā vai detektīva diskursā atrodami tādi atslēgvārdi kā varmāks, vara, pazudis u. c. Tipiskākie nosaukumu veidi nosauc varoṇa vārdu, varoṇa īpašību vai nodarbošanos, nosauc vai raksturo situāciju vai darbības vietu, citē kādu sentenci, pauž aizplīvurotu, noslēpumainu domu. Jebkuram nosaukumam jābūt tik efektīgam, lai ieinteresētu lasītāju par grāmatas saturu un rosinātu to izlasīt.

Bilžaino vāku rašanos noteica konkurence par lasītāju grāmatu tirgū. To lietošanas motivācija ir uzmanības pievēršana, lai krāsainais un uzkrītošais vāks izceltos melnbalto grāmatu masā un rosinātu ḷaužu iztēli un izšķiršanos par konkrētās grāmatas izvēli, tātad - reklāma. Vāka bildes un tā teksta nolūks ir piespiest lasītāju atvērt vāku. Šim mērḳim kalpoja pārdomāti izstrādāts vāka ansamblis - vāka bilde, piesaistošais nosaukums, kā arī intriǵējošais citāts.

\section{Bilžaino vāku rezonanse latviešu lasītāju auditorijā}

19. gadsimta otrajā pusē, pieaugot l̦aužu lasītprasmei un daiḷliteratūras, īpaši prozas

20 Смирдин Александр Филиппович. Энциклопедический словарь Брокгауза и Ефрона: в 86 m. Т. 30а. 1900. СПб.: Ф. А. Брокгауз, И. А. Ефрон, с. 528. grāmatu, piedāvājumam, lasāmvielas patēriņš kḷūst masveidīgs, pietiekami liels skaits cilvēku uz grāmatu lūkojas kā uz viņiem pieejamu relaksācijas līdzekli. Iestājas situācija, kad grāmatu skaits pārsniedz iespēju vienam cilvēkam tās visas izlasīt, sāk darboties konkurence izdevēju starpā, katrs cenšas laist klajā tādas grāmatas, kuras nodrošinātu noietu. Populārās literatūras jomā viena no sekmīgas pārdošanas metodēm ir spēja piesaistīt pircēja uzmanību. Vizuāli spilgti, uzkrītoši pasniegts iesain,ojums ir viens no piesaistes paṇēmieniem, un grāmatu vizìtkarte ir vāks. Vāka pievilcība šo cilvēku acīs bieži vien ir izšķiroša, izvēloties grāmatu uz tirgus letes vai kolportiera somā.

Jau gadsimtu gaitā bija pierādìts, ka attēls rosina lasīšanas interesi. Agrīnākie tautā iecienītākie bilžu veidi bija autoritāšu portreti (Pestītāja un citu svēto bildes, valdnieku un izcilu personu portreti). Lai ieinteresētu grāmatas lasīšanā, bildītes izmantoja bērnu lasīšanas mācībā. Tā K. Švānbergs, raksturojot Ernesta Dinsberga lasīšanas treniniem paredzētās “50 pasacinas ar bildēm”, îpašu vērtību saskata attēlos: "Šì īpaši to kūtrāku bērnu velk kā no miega ārā, jo kurš bērns nu bildes labprāt neskatīs [..]"21 Pakāpeniski tēlu galerija paplašinās ar literārajiem varoniem. Bilžainie vāki ne vien rāda lasītāju publikā aprobētos vēsturiskos personāžus, bet piedāvā iepazīt jaunus literārus tipus. Nav šaubu, ka bilžainie vāki veicināja triviālliteratūras izplatību, kas savukārt neatbilda sabiedrības ideolog̣isko vadītāju vēlmēm izkopt publikas literāri māksliniecisko gaumi. Tāpēc nopietnas, jēgpilnas literatūras aizstāvji ar izteiktu radikālismu vērsās pret skarbajiem asiņainajiem stāstiem un to attēliem. Viens no aktīvākajiem lubu literatūras apkarotājiem Andrejs Upīts - raksta: "Jo pasīvāks un mazdūšīgāks kāds cilvēks, jo vairāk vinš iejūsminās par tā varoṇa dūšu un revolveriem, kas uz burtnīcas vāka vai kinematogrāfa bildē. [..] viṇš ir

21 Švānbergs, K. 1868. Par lasīt mācīšanu mājās! Latviešu Avizzes (pielikums Baznīcas un skolas ziṇas), Nr. 39, 25. sept. (7. okt.), 78. lpp. 
simbols tai "mākslai", kas no neizglītotìbas un nospiestības sūc sev dzīvības sulu, kā parazītisks stīgu stāds, kas barojas no trūdoša koka miesas." 22 Tomēr kritiskie spriedumi vismaz acīmredzamā veidā neietekmēja l̦aužu izvēli. Bildes cilvēkiem patika.

Izdevēju aprēkins ar bildi piesaistīt pircējus sakn,ojas l̦aužu attieksmē pret attēlu jeb, kā toreiz sacīja, bildēm, bet "pervētas bildes" tika augstāk vērtētas par melnbaltajām. Pēteris Ērmanis (1893-1969) atceras, ka bildes pastiprinājušas lasītā iespaidus: "Viss, kas stāstā neomulīgs un baidīgs, bildē redzēts kḷūst divkārt ass un spilgts." ${ }^{23}$ Bēniņos viņš atradis stāstu "Krusta kalna pils", vienu no bērnības tumšajiem biediem, kas izraisījis bailes. Grāmatā "Sadedzināta parādu zīme" bijusi bilde, kur grāfs gatavojas šaut trīs blēžus, arī šì bilde, tāpat kā stāsts, izraisījusi nepatīkamas izjūtas. Arī rakstnieku Doku Ati (1861-1903) mazotnē bildes biedējušas. Viṇš

\section{AVOTI UN LITERATŪRA}

Apīnis, A. 1977. Latviešu grāmatniecība no pirmsākumiem lìdz 19. gadsimta beigām. Rīga: Liesma.

Bertram, C. H. 1872. Kādas ziṇas par grāmatu drukāšanu. Latviešu Avīzes, Nr. 29, 19. (30.) jūl., 229.-230. Ipp.

Bīlmanis, R. 1914. Latviešu lubu literatūras valstībā. No: Mūsu kalendārs 1915. gadam. Rīga: Izglītība.

Chabouillet, J. M. A. 1858. Catalogue général et raisonné des camées et pierres gravées de la Bibliotheque Impériale... Paris: Claye.

Delen, A. J. J. 1824. Histoire de la gravure dans les anciens Pays-Bas et les provinces Belges. Paris et Bruxelles: Les Editions d'Art et d'Histoire.

Doku, A. 1927. Mans dzives rīts. Rīga:Valters un Rapa, 22. Ipp.

22 Upīts, A. 1910. Šerloks Holms. No: Upīts, A. Studijas un kritikas. 1. sēj. Rīga: "Zvaigznes" izdevums, 73., 75. lpp.

23 Ērmanis, P. 1954. Atminuu vija. Čikāga: Alfrēds Kalnājs, 120. lpp. atceras: "Grāmatā bija kaulu cilvēks. Galva kā ola ar diviem melniem caurumiem, deguns nolauzts, roku stilbi, kāju stilbi, ribas... viss līdz nagu galiniem kauls kas kauls. [..] Man vai sirds riņ̧,ī griezās aiz liela riebuma un izbailēm." ${ }^{4}$ Turpretim Jānim Jaunsudrabiṇam (1877-1962) patikušas dinamiskas bildes: "Un kur tad vēl vesels pulks kara bilžu! Kā tur lodes gāja pa gaisu, kā putni, un kā plīsa, zemē nokritušas! [..] Krievs iedūris štiku turkam krūtīs; bet otrs turks, pagāns, sita krievu zaldātiņam ar plintes resgali pa galvu." 25

"Ikkatrai grāmatai toreiz bija sava seja. Tā bija bilde uz vāka, kurai vajadzēja attēlot brīniškīigos notikumus tur iekšā. Zilos svārkos un sarkanās biksēs tur rādījās nebēdīgi jūrnieki vai drošsirdīgi prēriju mednieki šautenēm plecos un dunčiem aiz jostas. Kuğis, kas pilnām burām dodas tālumā, solīja stāstus par piedzīvojumiem un svešām zemēm," bilžu burvības rezumējumu sniedzis Kārlis Skalbe. ${ }^{26}$

Ērmanis, P. 1954. Atmiṇu vija. Čikāga: Alfrēds Kalnājs.

Frīss, N. 1898. Cielavīte. Jelgava: J. Šablovskis.

Frīss, N. 1898. Ulāna sieva. Jelgava: J. Šablovskis.

Harthann J. 1997. The History of the illustrated Book: the Western tradition. London: Thames and Hudson.

lekšzemes zinas. 1897. Dienas Lapa, Nr. 100, 3. maijs, 2. Ipp.

Jaunsudrabiņš, J. 1914. Baltā grāmata. Rīga: [Dzirciemnieki], 81. Ipp.

Latvijas mākslas vēsture, 3. sēj., 2. gr., 1780-1890. 2019. Rīga: Latvijas Mākslas akadēmijas Mākslas vēstures institūts; Mākslas vēstures pētījumu atbalsta fonds, 173.-174. Ipp.

24 Doku, A. 1927. Mans dzīves rīts. Rīga: Valters un Rapa, 22. 1pp.

25 Jaunsudrabiņš, J. 1914. Baltā grāmata. Rīga: [Dzirciemnieki], 81. 1pp.

26 Skalbe, K. 1980. Manas grāmatnieka gaitas. No: Skalbe, K. Dzīvības siltums. Rīga: Liesma, 112. lpp. 
Law, G., Patten, R. L. 2009. The serial revolution. In: McKitterick, D. (ed.) The Cambrige history of the Book in Britain. Vol. 6, 1830-1914. Cambridge: Cambridge University Press, p. 144-171.

Lexikon der Buchkunst und der Bibliophilie. 2006. Hamburg: K. K. Walther.

Lexikon des gesamten Buchwesens. Bd. 1. 1987. Stuttgart: A. Hiersemann.

Lyons, M. 2010. History of Reading and Writing in the Western World. New York: Palgrave Macmillan, p. 138.

Misiņš, J. 1925. Latviešu rakstniecības rādītājs. 2. sēj. Rīga: Kultūras fonds, 18.-46. Ipp.

Schlagintweit, H. 1983. Reproduktionslithographie: Studien zur Funktion technischer, sozialer und komerzieller Vorgaben in der Bilderproduktion des 19. Jahrhunderts. Diss. München.

Schenda, R. 1966. Ein französischer Bilderbogenkatalog aus dem Jahre 1860. In: Schweizerisches Archiv für Volkskunde, Bd. 62, S. 52.
Schenda, R. 1977. Volk ohne Buch: Studien zur Sozialgeschichte der populären Lesestoffe, 1770-1910. München: Deutschen Taschenbuch-Verlag, S. $277-278$.

Skalbe, K. 1980. Manas grāmatnieka gaitas. No: Skalbe, K. Dzivïbas siltums. Rīga: Liesma, 112.-114. Ipp.

Švānbergs, K. 1868. Par lasīt mācīšanu mājās! Latviešu Avīzes (pielikums Baznīcas un skolas ziṇas), Nr. 39, 25. sept. (7. okt.), 78.-79. Ipp.

Upīts, A. 1910. Šerloks Holms. No: Upīts A. Studijas un kritikas. 1. sēj. Rīga: "Zvaigznes" izdevums, 66.-75. Ipp.

Villerušs, V. 1986. 19. gadsimta latviešu grāmatu tipogrāfisko papīra vāku informatīvā funkcija. No: Grāmatas un grāmatnieki: Misin, bibliotēkas 100. gadadienai, 1885-1985. 2. izd. Rīga: Zinātne, 146.-159. Ipp.

Смирдин Александр Филиппович. 1900. Энциклопедический словарь Брокгауза и Ефрона: в 86 m. Т. 30а. СПб.: Ф. А. Брокгауз, И. А. Ефрон, с. 528. 